\title{
Enhanced Production of Gellan by Sphingomonas paucibilis NK-2000 with Shifts in Agitation Speed and Aeration Rate after Glucose Feeding into the Medium
}

\author{
Nam-Kyu Lee, Hyung-Phil Seo, Young-Bai Cho, Chang-Woo Son ${ }^{1}$, Wa Gao ${ }^{2,3}$ and Jin-Woo Lee ${ }^{2,4 *}$ \\ Marine-Bioindustry Development Center, Busan 619-912, Korea \\ ${ }^{1}$ Korea Biosolution Co., Busan 612-020, Korea \\ ${ }^{2}$ BK21 Bio-Silver Group of Dong-A University, Busan 604-714, Korea \\ ${ }^{3}$ Depatment of Medical Science of Graduate School of Dong-A University, Busan 604-714, Korea \\ ${ }^{4}$ Department of Biotechnology, Dong-A University, Busan 604-714, Korea
}

Received February 3, 2010 /Accepted June 14, 2010

\begin{abstract}
Optimal agitation speed and aeration rate for the production of gellan by Sphingomnas paucibilis NK2000 in a 71 bioreactor were found to be $400 \mathrm{rpm}$ and $1.0 \mathrm{vvm}$. The best time for glucose feeding into the medium for enhanced production of gellan by S. paucibilis NK2000 was $36 \mathrm{hr}$ after cultivation. The concentrations of gellan produced by S. paucibilis NK2000 from 1) $20.0 \mathrm{~g} / 1$ glucose without additional feeding, 2) $20.0 \mathrm{~g} / 1$ glucose with feeding of $200.0 \mathrm{~g} / 1$ glucose at $36 \mathrm{hr}$, in which the final concentration in the medium was $10.0 \mathrm{~g} / \mathrm{l}, 3) 20 \mathrm{~g} / 1$ glucose with feeding of $200.0 \mathrm{~g} / 1$ glucose and a shift in an agitation speed from 400 to $600 \mathrm{rpm}$, 4) $20.0 \mathrm{~g} / 1$ glucose with feeding of $200.0 \mathrm{~g} / 1$ glucose at $36 \mathrm{hr}$ and shifts in an agitation speed from 400 to $600 \mathrm{rpm}$ and an aeration rate from 1.0 to $1.5 \mathrm{vvm}$, 5) and $20.0 \mathrm{~g} / 1$ glucose with feeding of $200.0 \mathrm{~g} / 1$ glucose at $36 \mathrm{hr}$ and shifts in an agitation speed from 400 to $600 \mathrm{rpm}$ and an aeration rate from 1.0 to $2.0 \mathrm{vvm}$, were 5.19, 5.74, 6.73, 7.93, and 9.40 $\mathrm{g} / \mathrm{l}$, respectively, and their conversion rates from glucose were 26.0, 19.1, 22.4, 26.4, and 31.3\%, respectively. Compared to those developed using a normal process, production of gellan by $S$. paucibilis NK2000 from $20.0 \mathrm{~g} / 1$ glucose was 1.81 times higher, and and its conversion rate was 1.20 times higher when the optimized process developed in this study was used.
\end{abstract}

Key words : Sphingomnas paucibilis, gellan, glucose feeding, agitation speed, aeration rate

\section{Introduction}

Gellan, a commercial gelling agent, is an extracellular polysaccharide produced by Sphingomnas paucibilis (formerly Pseudomonas elodea) [9,17]. Gellan consists of linear repeating tetrasaccharides, which is composed of D-glucose (Glc), D-glucuronic acid (GlcA), and L-rhamnose residues (Rha) $[8,9]$. Gellan exhibits good stability, which is a distinct advantage in fruit-based products [12]. It has approval in the USA and EU for food use as gelling, stabilizing and suspending agents [19]. Gellan has also been used for immobilization of enzymes and cells as well as gel electrophoresis. Recent reports indicate that the annual production of gelatin is nearly 326,000 tons [13]. One of the possible gelatin alternatives for the food industry is gellan [18].

Factors that affect the production of gellan are carbon and nitrogen sources, temperature, the initial $\mathrm{pH}$ of the medium, and oxygen supply $[1,4,14]$. Effects of agitation and aeration

\footnotetext{
*Corresponding author

Tel : +82-51-200-7593, Fax : +82-51-200-7505

E-mail : jwlee@dau.ac.kr
}

on the production of gellan and its molecular weight have been reported [7]. Agitation speed and aeration rate, which affect the concentration of dissolved oxygen (DO) in culture broths are important in aerobic fermentation processes particularly in polysaccharide production, since the broth becomes highly viscous and limits mass and oxygen transfer which influence the cellular activities and secondary metabolite production [3]. Production of gellan is accompanied by a considerable increase in viscosity as the time of cultivation passes, which leads to a reduction of oxygen supply [6]. Due to viscous and pseudoplastic characteristics of its culture broth, the production of gellan requires high agitation to promote enough concentration of dissolved oxygen in the medium [6,22]. However, an increase in agitation speed means more energy consumed for the production of gellan, and can lead to mechanical damage to the polysaccharide [20]. Studies on strategy for control of agitation speed for enhanced production of gellan by $S$. paucimobilis have been scarce.

Production of gellan is a closely growth-associated process, and thus a factor or process variable that stimulate cell 
growth should enhance it production [21]. The carbon source supporting the maximum cell growth results in the maximum production of gellan [2]. However, higher concentrations of carbon sources, especially glucose, inhibit cell growth as well as the production of gellan due to their catabolite repression [21]. The concentrations of gellan produced by $S$. paucimobilis ranged from 6.0 to $17.7 \mathrm{~g} / 1$ dependent on kinds of carbon sources and their concentration [2,11,21]. Higher concentration of starch can enhance the production of gellan, however, which interferes with the recovery of gellan from culture broth [2]. Higher production and conversion rate of gellan from glucose were obtained in a fed-batch fermentation, which overcame the catabolite repression and supported the higher production of gellan $[11,21]$.

Previous study was to develop cheap nitrogen sources instead of yeast extract or peptone for the production of gellan by S. paucimobilis NK-2000 [10]. Soybean pomace was substituted for yeast extract as a nitrogen source for production of gellan, which could reduce the cost. Soybean pomace is a by-product from the soy sauce industry and about 20,000 tons are generated each year in the Republic of Korea. In this study, the effect of agitation speed and aeration rate as well as shifts in agitation speed and aeration rate after glucose feeding into the medium on the production of gellan was investigated in order to solve the problem regarding mixing and oxygen supply, which is believed to enhance its productivity.

\section{Materials and Methods}

\section{Bacterial strain and medium}

Sphingomnas paucibilis NK2000 (formerly Pseudomonas elodea) is a UV-induced mutant of S. paucibilis ATCC 31461, which was purchased from American Type Culture Collection (ATCC). The medium used for cell growth and production of gellan contained $20.0 \mathrm{~g} / 1$ glucose, $10.0 \mathrm{~g} / 1$ soybean pomace, $0.5 \mathrm{~g} / 1 \mathrm{~K}_{2} \mathrm{HPO}_{4}, 0.1 \mathrm{~g} / 1 \mathrm{MgSO}_{4} \cdot 7 \mathrm{H}_{2} \mathrm{O}$, and 0.1 $\mathrm{ml}$ mineral salt solution [10]. The mineral salt solution contained $1.8 \mathrm{~g} / 1 \mathrm{MnCl}_{2} \cdot 4 \mathrm{H}_{2} \mathrm{O}, 2.49 \mathrm{~g} / 1 \mathrm{FeSO}_{4} \cdot 7 \mathrm{H}_{2} \mathrm{O}, 0.29 \mathrm{~g} / 1$ $\mathrm{H}_{3} \mathrm{BO}_{3}, 27.0 \mathrm{~g} / 1 \mathrm{CuCl}_{2}, 21.0 \mathrm{~g} / 1 \mathrm{ZnCl}_{2}, 74 \mathrm{~g} / 1 \mathrm{CoCl}_{2} \cdot 6 \mathrm{H}_{2} \mathrm{O}$, $23.0 \mathrm{~g} / 1 \mathrm{MgMoO}_{4}$, and $2.1 \mathrm{~g} / 1$ sodium tartrate (dihydrate). The $\mathrm{pH}$ of the medium was adjusted to 6.5-6.8 before sterilization. The carbon source was autoclaved separately for $15 \mathrm{~min}$ at $121^{\circ} \mathrm{C}$ and added to the medium under aseptic conditions. The soybean pomace used in this study was a by-product from a domestic factory (O-Bok Food Co., Korea), which produces traditional Korean foods.

\section{Production of gellan}

Starter cultures were prepared by transferring cells from agar slants to $100 \mathrm{ml}$ of the medium with $20.0 \mathrm{~g} / 1$ glucose and $2.5 \mathrm{~g} / 1$ yeast extract in $500 \mathrm{ml}$ Erlenmeyer flasks. These cultures were incubated at $30^{\circ} \mathrm{C}$ for 1 day with an agitation speed of $200 \mathrm{rpm}$. These starter cultures were used as inoculum for a 51 medium with $20.0 \mathrm{~g} / 1$ glucose and 10.0 $\mathrm{g} / 1$ soybean pomace in a 71 bioreactor (Ko-Biotech Co., Korea). Working volumes of the 71 bioreactors were 51 and inoculum size of batch fermentations for production of gellan by S. paucibilis NK2000 was 5.0\% (v/v). Agitation speeds ranged from 200 to $400 \mathrm{rpm}$ and aeration rates ranged from 0.5 to $2.0 \mathrm{vvm}$. Samples were periodically withdrawn from the culture to determine cell growth and production of gellan.

To isolate gellan, the culture broth was heated at $95^{\circ} \mathrm{C}$ for $15 \mathrm{~min}$ in a boiling water bath. The $\mathrm{pH}$ of the heated culture broth was adjusted to 10.0 by $2.0 \mathrm{~N} \mathrm{NaOH}$ and neutralized with $2.0 \mathrm{~N} \mathrm{H}_{2} \mathrm{SO}_{4}$. The pretreated broth was centrifuged at $12,000 \times \mathrm{g}$ for $20 \mathrm{~min}$ to separate the cells. The supernatant was mixed with $2 \mathrm{vol}$ of isopropanol and then kept overnight at $4^{\circ} \mathrm{C}$. This precipitated gellan was centrifuged at $8,000 \times \mathrm{g}$ for $30 \mathrm{~min}$ and dried at $100-105^{\circ} \mathrm{C}$ until constant weight [16].

\section{Analytical methods}

Cell growth was determined by directly weighing biomass after drying to a constant weight at $100-105^{\circ} \mathrm{C}$. Production of gellan and reducing sugar were determined by a method described in a previous report [10].

\section{Results and Discussion}

\section{Effect of agitation speed on production of gellan}

The effect of agitation speed on cell growth and the production of gellan by S. paucibilis NK2000 was investigated in a 71 bioreactor (Ko-Biotech Co., Korea). Agitation speed ranged from 200 to $500 \mathrm{rpm}$ and aeration rate was $1.0 \mathrm{vvm}$. The temperature and initial $\mathrm{pH}$ of the medium for the production of gellan by S. paucibilis NK2000 were $30^{\circ} \mathrm{C}$ and 6.8 , respectively. A higher agitation speed, which resulted in an increase of dissolved oxygen in the medium, enhanced cell growth, as shown in Fig. 1A. The optimal agitation speed 
for cell growth of S. paucibilis NK2000 was found to be 400 rpm. Production of gellan by S. paucibilis NK2000 also increased with elevated agitation speed, as shown in Fig. 1B. The optimal agitation speed for production of gellan was also $400 \mathrm{rpm}$. The highest production of gellan by S. paucibilis NK2000 was $5.55 \mathrm{~g} / 1$ from $20.0 \mathrm{~g} / 1$ glucose and $10.0 \mathrm{~g} / 1$ soybean pomace as carbon and nitrogen sources. Production of gellan was increased according to cell growth of S. paucibilis NK2000 [10]. It seems that higher concentrations of dissolved oxygen in the medium promote cell growth of $S$. paucibilis NK2000, which results in higher production of gellan.

\section{Effect of aeration rate on production of gellan}

The effect of aeration rate on cell growth and the production of gellan by S. paucibilis NK2000 was also investigated. Aeration rate ranged from 0.5 to $2.0 \mathrm{vvm}$ and agitation speed was $400 \mathrm{rpm}$. Optimal aeration rates for cell
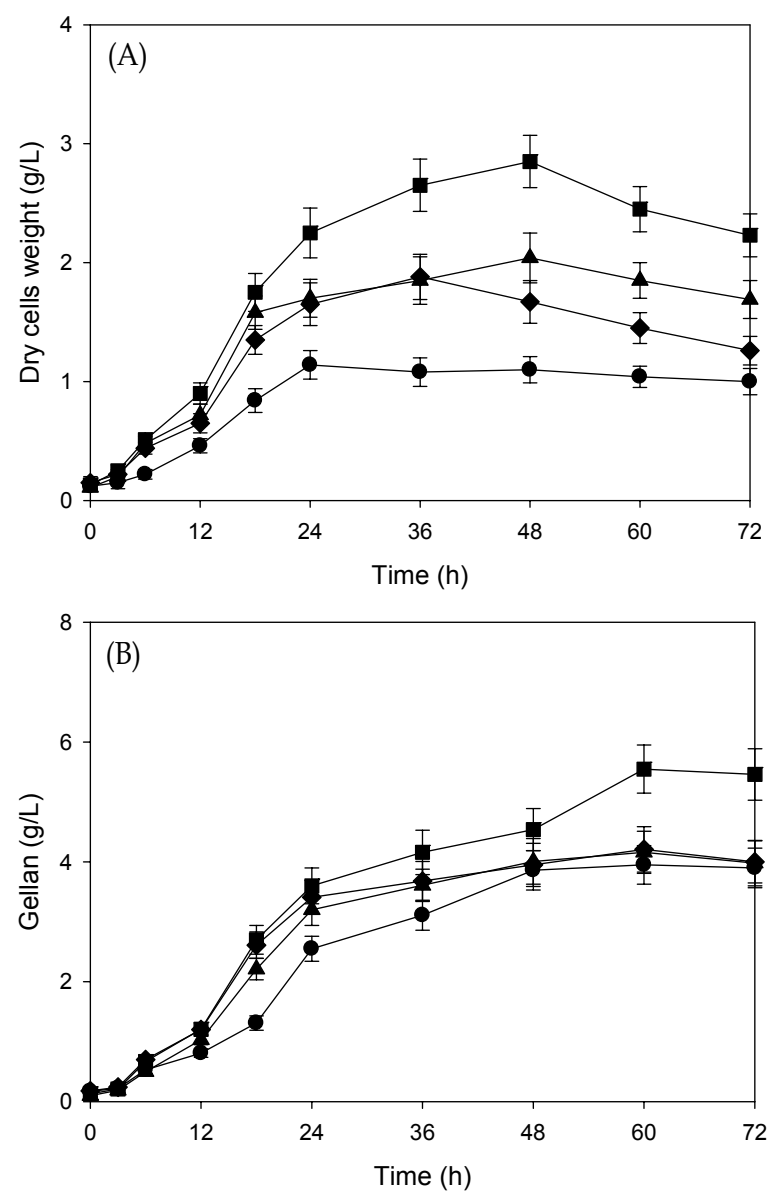

Fig. 1. Effect of agitation speed on cell growth (A) and the production of gellan (B) by S. paucibilis NK2000 (-, 200 rpm; $\boldsymbol{\Delta}, 300 \mathrm{rpm}$; $\mathbf{\square}, 400 \mathrm{rpm}$, and $\diamond, 500 \mathrm{rpm}$ ). growth of S. paucibilis NK2000 as well as for production of gellan were $1.0 \mathrm{vvm}$, as shown in Fig. 2. The highest production of gellan by S. paucibilis NK2000 was $5.65 \mathrm{~g} / 1$ with an agitation speed of $400 \mathrm{rpm}$ and an aeration rate of 1.0 vvm. The concentration of dissolved oxygen in the medium can be influenced by agitation speed, aeration rate, and the inner pressure of bioreactors [6,7]. It seems that higher dissolved oxygen in the medium due to higher aeration rates and agitation speeds, leads to enhance cell growth, which resulted in improved production of gellan.

Effect of glucose feeding time on production of gellan

The effect of glucose feeding into the culture broth at different time on cell growth and the production of gellan by S. paucibilis NK2000 was investigated. Agitation speed and aeration rate for the production of gellan by $S$. paucibilis
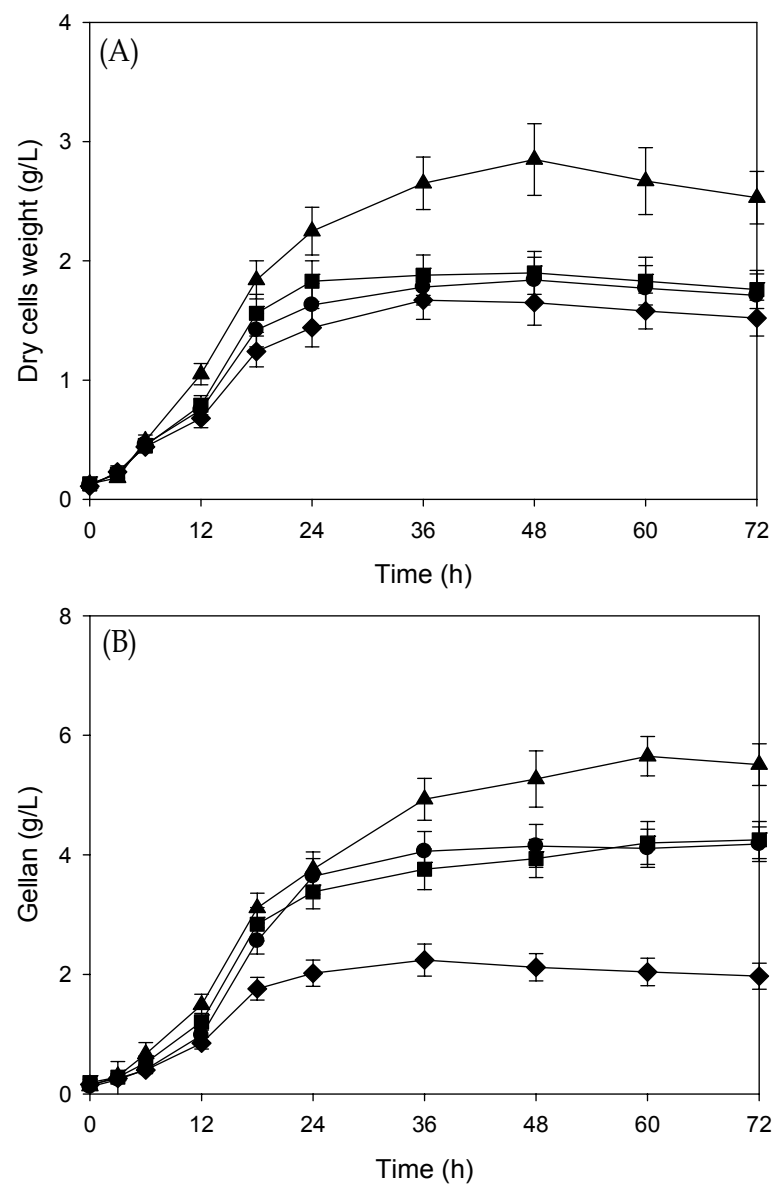

Fig. 2. Effect of aeration rate on cell growth (A) and the production of gellan (B) by S. paucibilis NK2000 (, $0.5 \mathrm{vvm;}$ $\boldsymbol{\Delta}, 1.0 \mathrm{vvm} ; \mathbf{\square}, 1.5 \mathrm{vvm}$, and $\diamond, 2.0 \mathrm{vvm})$. 
NK2000 were $400 \mathrm{rpm}$ and $1.0 \mathrm{vvm}$. Concentration of glucose in the feeding solution was $200.0 \mathrm{~g} / 1$ and its final concentration of glucose fed into the medium was $10.0 \mathrm{~g} / 1$. Reducing sugars in culture broths increased from 18.9 to 29.2 $\mathrm{g} / 1$, from 8.4 to $18.2 \mathrm{~g} / 1$, from 4.4 to 14.1 , and from 2.4 to $12.1 \mathrm{~g} / 1$ with glucose feeding after $0,24,36$, and $48 \mathrm{hr}$ culti-
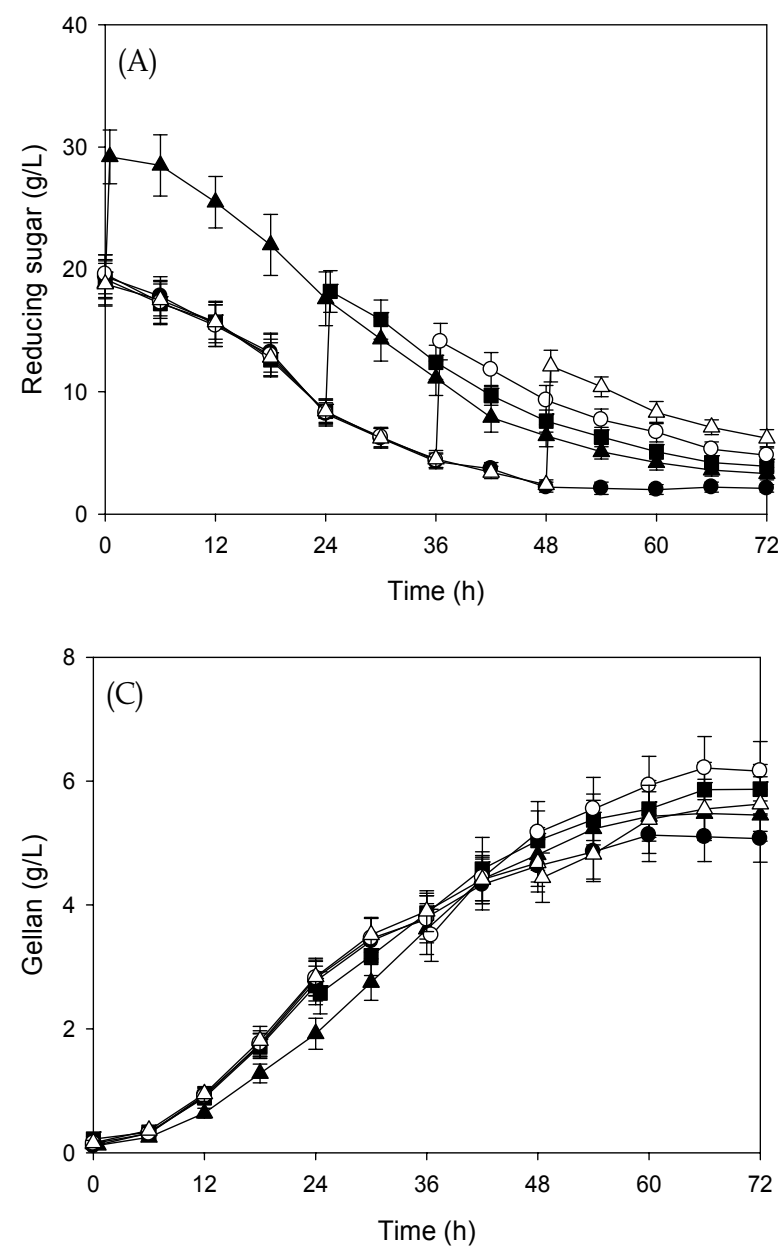

vation, respectively, as shown in Fig. 3A. Production of gellan from $20.0 \mathrm{~g} / 1$ glucose without glucose feeding was 5.07 $\mathrm{g} / \mathrm{l}$, whereas those from $20.0 \mathrm{~g} / 1$ glucose with feeding of glucose feeding at a different time ranged from 5.45 to 6.16 $\mathrm{g} / \mathrm{l}$, as shown in Table 1 . Significance of each value was analyzed by DPS software version 3.01 (DPS Co., Middlesex,

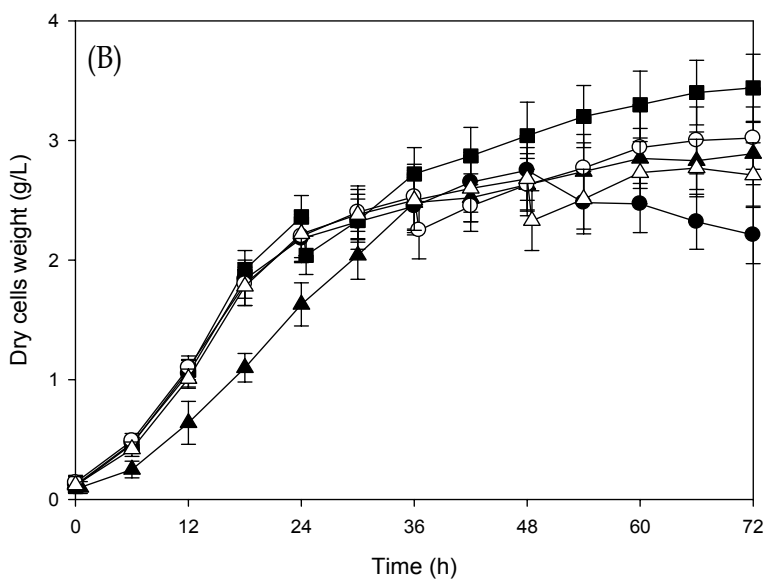

Fig. 3. Effect of feeding time for the final concentration of 100.0 $\mathrm{g} / \mathrm{l}$ glucose into the medium on reducing sugars (A), cell growth (B), and the production of gellan by $S$. paucibilis NK2000 (C) in a 71 bioreactor ( $\bullet$, no adding; $\mathbf{\square}$, feeding at $0 \mathrm{hr}^{*} ; \mathbf{\Lambda}$, feeding at $24 \mathrm{hr}^{*} ; \mathrm{O}$, feeding at $36 \mathrm{hr}^{*}$; and $\square$, feeding at $48 \mathrm{hr}^{*}$; Significance of each value was analyzed by DPS software version 3.01 (DPS Co., Middlesex, UK). Values with different letters are significantly different at $p<0.05$.)

Table 1. Effect of feeding time for the final concentration of $10.0 \mathrm{~g} / 1$ glucose in the medium on cell growth and the production of gellan by S. paucibilis NK2000 for $72 \mathrm{hr}$ cultivation

\begin{tabular}{cccccccc}
\hline $\begin{array}{c}\text { Feeding } \\
\text { time }(\mathrm{hr})\end{array}$ & Final pH & $\begin{array}{c}\text { DCW } \\
(\mathrm{g} / \mathrm{l})\end{array}$ & $\begin{array}{c}\text { Gellan } \\
(\mathrm{g} / \mathrm{l})\end{array}$ & $\begin{array}{c}\text { Reducing } \\
\text { sugars }(\mathrm{g} / \mathrm{l})\end{array}$ & $\mathrm{Y}_{\mathrm{x} / \mathrm{s}}{ }^{1}$ & $\mathrm{Y}_{\mathrm{p} / \mathrm{s}}{ }^{2}$ & $\mathrm{Y}_{\mathrm{p} / \mathrm{x}}{ }^{3}$ \\
\hline No feeding & 5.6 & $2.21 \pm 0.22^{\mathrm{c} 4}$ & $5.07 \pm 0.32^{\mathrm{b}}$ & $2.11 \pm 0.25^{\mathrm{d}}$ & 0.11 & 0.25 & 2.29 \\
0 & 5.5 & $2.89 \pm 0.24^{\mathrm{b}}$ & $5.45 \pm 0.34^{\mathrm{ab}^{*} 4}$ & $3.32 \pm 0.28^{\mathrm{c}^{*}}$ & 0.10 & 0.18 & 1.89 \\
24 & 5.6 & $3.44 \pm 0.22^{\mathrm{a}}$ & $5.87 \pm 0.35^{\mathrm{b}^{*}}$ & $3.91 \pm 0.36^{\mathrm{c}^{*}}$ & 0.11 & 0.20 & 1.71 \\
36 & 5.8 & $3.02 \pm 0.23^{\mathrm{b}}$ & $6.16 \pm 0.42^{\mathrm{a}^{*}}$ & $4.84 \pm 0.42^{\mathrm{b}^{*}}$ & 0.10 & 0.21 & 2.04 \\
48 & 6.0 & $2.71 \pm 0.18^{\mathrm{b}}$ & $5.63 \pm 0.33^{\mathrm{ab}^{*}}$ & $6.37 \pm 0.49^{\mathrm{a}^{*}}$ & 0.09 & 0.19 & 2.00 \\
\hline
\end{tabular}

${ }^{1}$ yield of $\mathrm{g}$ dry cells weight/g glucose

2yield of g gellan/g glucose

${ }^{3}$ yield of $g$ gellan/g dry cells weight

${ }^{4 *}$ Values with different letters are significantly different at $p<0.05$. 
UK). Values with different letters are significantly different at $\mathrm{p}<0.05$.

The best feeding time of glucose for cell growth was not the same as that for the production of gellan by $S$. paucibilis NK2000, as shown Fig. 3B and C. The highest cell growth of S. paucibilis NK2000 was obtained when $200.0 \mathrm{~g} / 1$ glucose was fed into the culture broth after $24 \mathrm{hr}$ cultivation, whereas the highest production of gellan was obtained when the same concentration of glucose was fed into the culture broth after $36 \mathrm{hr}$ cultivation. Glucose, as a carbon source, seems to be first utilized for cell growth of S. paucibilis NK2000 and then biosynthesis of precursors for production of gellan. The highest production of gellan from $20.0 \mathrm{~g} / 1$ glucose with feeding of $200.0 \mathrm{~g} / 1$ glucose after $36 \mathrm{hr}$ of cultivation was $6.16 \mathrm{~g} / \mathrm{l}$, which conversion rate was $20.5 \%$. Fed-batch culture is a batch culture fed continuously or sequentially with substrate without the removal of fermentation broth, which is generally superior to batch and continuous cultures [5].

\section{Effect of shifts in agitation speed and aeration rate on production of gellan}

Cell growth and production of gellan by five different processes were compared to investigate the effect of shifts in agitation speed and aeration rate after feeding of glucose into the medium. Its final concentration of glucose fed into the medium was $10.0 \mathrm{~g} / 1$. Concentrations of dissolved oxygen in culture broths rapidly decreased and reached around $0 \%$ after $36 \mathrm{hr}$ of cultivation. Concentrations of dissolved oxygen after a shift in an agitation speed from 400 to 600 rpm, shifts in an agitation speed from 400 to $600 \mathrm{rpm}$ and
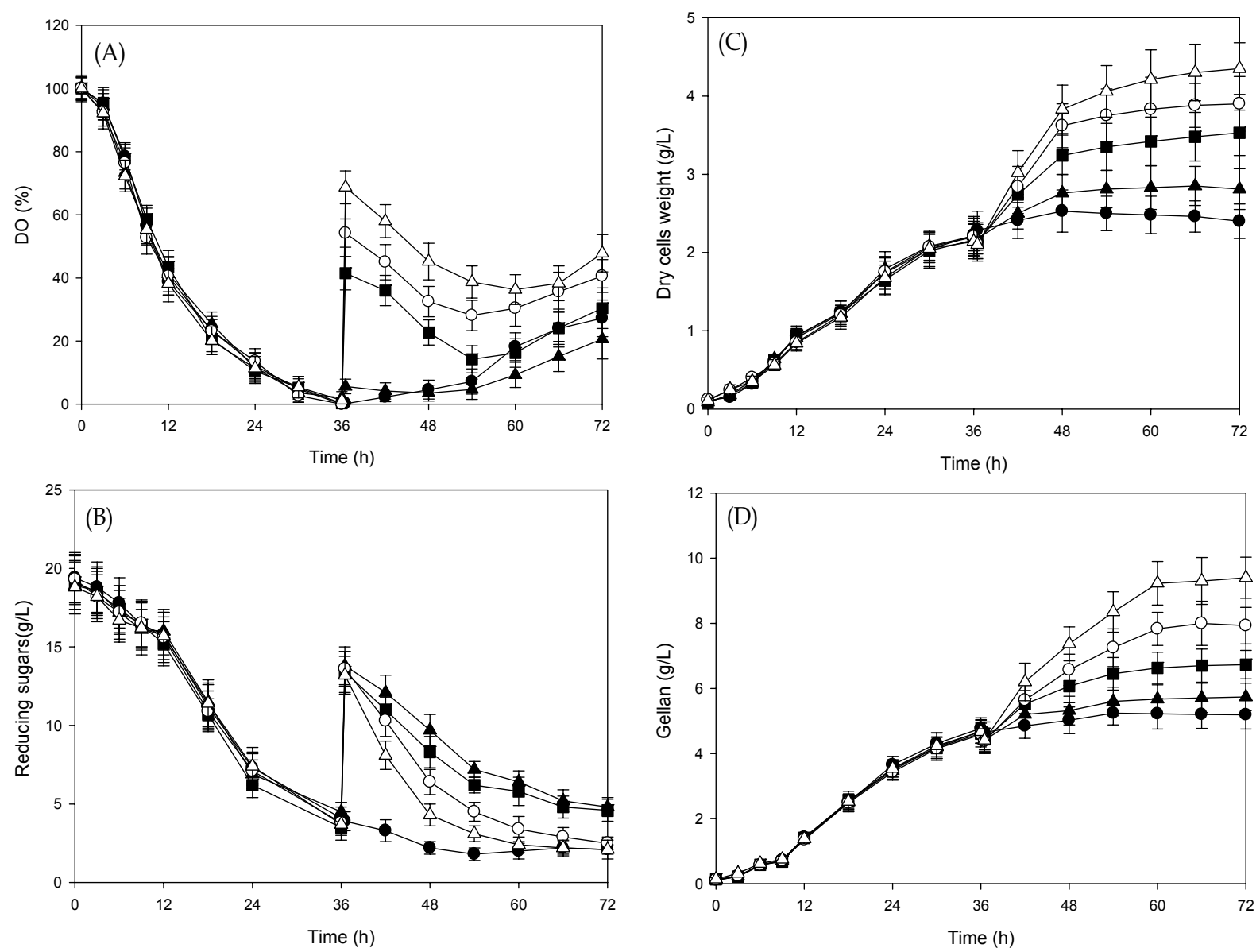

Fig. 4. Effect of feeding of the final concentration of $10.0 \mathrm{~g} / 1$ glucose and shifts of agitation speed and aeration rate on dissolved oxygen in the medium (A), reducing sugars (B), cell growth (C), and the production of gellan (D) by S. paucibilis NK2000 (๑, without feeding; $\mathbf{\Lambda}$, feeding at $36 \mathrm{hr} ; \mathbf{\square}$, feeding at $36 \mathrm{hr}$ and a shift of a agitation speed from 400 to $600 \mathrm{rpm}^{*}$; $\mathrm{O}$, feeding at $36 \mathrm{hr}$ and shifts of an agitation speed from 400 to $600 \mathrm{rpm}$ and an aeration rate from 1.0 to $1.5 \mathrm{vvm}^{*}$, and $\triangle$, feeding at $36 \mathrm{hr}$ and shifts of an agitation speed from 400 to $600 \mathrm{rpm}$ and an aeration rate from 1.0 to $2.0 \mathrm{vvm}^{*}$ ). 
Table 2. Effect of shifts in agitation speed and aeration rate after glucose feeding on cell growth and the production of gellan by S. paucibilis NK2000

\begin{tabular}{|c|c|c|c|c|c|c|c|}
\hline \multirow{2}{*}{ Process } & \multirow{2}{*}{$\begin{array}{c}\text { Glucose }^{1} \\
(\mathrm{~g} / \mathrm{l})\end{array}$} & \multicolumn{2}{|c|}{ Agitation speed (rpm) } & \multicolumn{2}{|c|}{ Aeration rate (vvm) } & \multirow{2}{*}{$\begin{array}{c}\text { DCW } \\
(\mathrm{g} / \mathrm{l})\end{array}$} & \multirow{2}{*}{$\begin{array}{c}\text { Gellan } \\
(\mathrm{g} / \mathrm{l})\end{array}$} \\
\hline & & Before $^{2}$ & After $^{3}$ & Before & After & & \\
\hline 1 & 20 & 400 & 400 & 1.0 & 1.0 & $2.40 \pm 0.32^{c 4}$ & $5.19 \pm 0.42^{\mathrm{d}}$ \\
\hline 2 & 30 & 400 & 400 & 1.0 & 1.0 & $2.81 \pm 0.24^{\mathrm{c}}$ & $5.74 \pm 0.36^{\mathrm{cd}^{\mathrm{d}_{4}}}$ \\
\hline 3 & 30 & 400 & 600 & 1.0 & 1.0 & $3.53 \pm 0.31^{\mathrm{b}^{*}}$ & $6.73 \pm 0.58^{\mathrm{c}^{* 4}}$ \\
\hline 4 & 30 & 400 & 600 & 1.0 & 1.5 & $3.90 \pm 0.36^{\mathrm{ab}^{*}}$ & $7.93 \pm 0.61^{\mathrm{b}^{*}}$ \\
\hline 5 & 30 & 400 & 600 & 1.0 & 2.0 & $4.35 \pm 0.42^{\mathrm{a}^{*}}$ & $9.40 \pm 0.85^{\mathrm{a}^{*}}$ \\
\hline
\end{tabular}

${ }^{1}$ final concentration of glucose as a carbon source in the medium after feeding of $200.0 \mathrm{~g} / 1$ glucose

agitation speed before $36 \mathrm{hr}$ cultivation

3 agitation speed after $36 \mathrm{hr}$ cultivation

${ }^{4_{*}}$ Values with different letters are significantly different at $p<0.05$.

an aeration rate from 1.0 to $1.5 \mathrm{vvm}$, and shifts in an agitation speed from 400 to $600 \mathrm{rpm}$ and an aeration rate from 1.0 to 2.0 vvm were increased to $41.5,54.2$, and $68.7 \%$, respectively, as shown in Fig. 4A. Reducing sugars in culture broths were about $3.0 \mathrm{~g} / 1$ after $36 \mathrm{hr}$ cultivation and those after glucose feeding increased to about $13.0 \mathrm{~g} / \mathrm{l}$. Consumption rates of reducing sugars after glucose feeding increased with elevated agitation speeds and aeration rates, as shown in Fig. 4B. Elevated concentrations of dissolved oxygen (DO) in the culture broth by shifts in agitation speeds were reported to enhance productivity of microbial metabolites [14,22].

Cell growths of S. paucibilis NK2000, measured as dry cells weight (DCW), from $20.0 \mathrm{~g} / 1$ glucose without feeding, 20.0 $\mathrm{g} / 1$ with feeding of $200.0 \mathrm{~g} / 1$ glucose at $36 \mathrm{~h}, 20.0 \mathrm{~g} / 1$ glucose with feeding of $200.0 \mathrm{~g} / 1$ glucose at $36 \mathrm{hr}$ and a shift in an agitation speed from 400 to $600 \mathrm{rpm}, 20.0 \mathrm{~g} / 1$ glucose with feeding of $200.0 \mathrm{~g} / 1$ glucose at $36 \mathrm{hr}$ and shifts in an agitation speed from 400 to $600 \mathrm{rpm}$ and an aeration rate from 1.0 to $1.5 \mathrm{vvm}$, and $20.0 \mathrm{~g} / 1$ glucose with feeding of $200.0 \mathrm{~g} / 1$ glucose at $36 \mathrm{hr}$ and shifts in an agitation speed from 400 to $600 \mathrm{rpm}$ and an aeration rate from 1.0 to 2.0 vvm, were $2.40,2.81,3.53,3.90$, and $4.35 \mathrm{~g} / \mathrm{l}$, respectively, as shown in Table 2 and Fig. 4C. Productions of gellan by S. paucibilis NK2000 from those of five different processes were 5.19, 5.74, 6.73, 7.93, and $9.40 \mathrm{~g} / \mathrm{l}$, respectively, and their conversion rates from glucose as a carbon source were 26.0, 19.1, 22.4, 26.4, and 31.3\%, as shown in Table 2 and Fig. 4D. Production of gellan and its conversion rate by $S$. paucibilis NK2000 from $20.0 \mathrm{~g} / 1$ glucose as a carbon source with feeding of $200.0 \mathrm{~g} / 1$ glucose at $36 \mathrm{hr}$ and shifts in an agitation speed from 400 to $600 \mathrm{rpm}$ and an aeration rate of 1.0 to $2.0 \mathrm{vvm}$ were $9.40 \mathrm{~g} / 1$ and $31.3 \%$, which were 1.81 and 1.20 times higher than those without feeding as well as shifts in an agitation speed and an aeration rate. The investigation of intermediate two-step addition of glucose under identical conditions of fermentation showed an enhanced production of gellan with a concentration of $8.1 \mathrm{~g} / 1$ as compared with the control of $6.0 \mathrm{~g} / 1$ [11]. There are several reports with respect to the application of shifts in an agitation speed, an aeration rate, temperature, and/or $\mathrm{pH}$ of culture medium during cultivation to enhance productivity of microbial metabolites [15,23-25]. In this study, a simple process was developed to enhance production of gellan with shifts in an agitation speed and an aeration rate after glucose feeding at an optimal time.

\section{Acknowledgment}

This study was supported by research funds from Dong-A University, Busan, Korea.

\section{References}

1. Arockiasamy, S. and R. M. Banik. 2008. Optimization of gellan gum production by Sphingmonas paucimobilis ATCC 31461 with nonionic surfactants using central composite design. J. Biosci. Bioeng. 105, 203-210.

2. Bajaj, I. B., P. S. Saudagar, R. S. Singhal, and A. Pandey. 2006. Statistical approach to optimization of fermentative production of gellan gum from Sphingomonas paucimobilis ATCC 31461. J. Biosci. Bioeng. 102, 150-156.

3. Banik, R. M. and A. Santhiago. 2006. Improvement in production and quality of gellan gum by Sphingomonas paucimobilis under high dissolved oxygen tension levels. Biotechnol. Lett. 28, 1347-1350.

4. Banik, R. M., A. Santhiagu, and S. N. Upadhyay. 2006. Optimization of nutrients for gellan gum production by Sphingmonas paucimobilis ATCC-31461 in molasses based me- 
dium using response surface methodology. Bioresource Technol. 98, 792-797.

5. Ding, S. and T. Tan. 2006. L-lactic acid production by Lactobacillus casei fermentation using different fed-batch feeding strategies. Process Biochem. 41, 1451-1454.

6. Dreveton, E., F. Monot, D. Ballerini, J. Lecourtier, and L. Choplin. 1994. Effect of mixing and mass transfer conditions on gellan production by Auromonas elodea. J. Ferment. Bioeng. 77, 642-649.

7. Giavasis, I., L. M. Harvey, and B. McNeil. 2006. The effect of agitation and aeration on the synthesis and molecular weight of gellan in batch cultures of Sphingomonas paucimobilis. Enzyme Microb. Technol. 38, 101-108.

8. Harding, N. E., Y. N. Patel, and R. J. Coleman. 2004. Organization of genes required for gellan polysaccharide biosynthesis in Sphingomonas elodea ATCC 31461. J. Ind. Microbiol. Biotechnol. 31, 70-82.

9. Jansson, R. E., B. Lindberg, and P. L. A. Sandford. 1983. Structural studies of gellan gum, an extracellular polysaccharide elaborated by Pseudomonas elodea. Carbohydr. Res. 124, 135-139.

10. Jin, H., N. K. Lee, M. K. Shin, S. K. Kim, D. L. Kaplan, and J. W. Lee. 2003. Production of gellan gum by Sphingomanas paucimobilis NK200 with soybean pomace. Biochem. Eng. J. 16, 357-360.

11. Kanari, B., R. R. Banik, and S. N. Upadhyay. 2002. Effect of environmental factors and carbohydrate on gellan gum production. Appl. Biocehm. Biotechnol. 102-103, 129-140.

12. Kang, K. S., G. T. Veeder, P. J. Mirrasoul, T. K. Kaneko, and L. W. Cottrell. 1982. Agar-like polysaccharide produced by a Pseudomonas species: production and basic properties. Appl. Environ. Mircobiol. 43, 1086-1091.

13. Karim, A. A. and R. Bhat. 2009. Fish gelatin: properties, challenge, and prospects as an alternative to mammalian gelatins. Food Hydrocolloids 23, 563-576.

14. Lee, N. K., Y. B. Jo. I. H. Jin, C. W. Son, and J. W. Lee. 2009. The effect of potassium phosphate as a $\mathrm{pH}$ stabilizer on the production of gellan by Sphingmonas paucibilis NK-2000. J. Life Sci. 8, 1033-1035.

15. Li, Y., J. Hugenholtz, J. Chen, and S. Lun. 2002. Enhancement of pyruvate production by Torulopsis glabrata using a two-stage oxygen supply control strategy. Appl. Microbiol. Biotechnol. 60, 101-106.

16. Lim, S. M., J. R. Ru, J. W. Lee, and S. K. Kim. 2003. Optimization of culture condition for the gellan production by Pseudomonas elodea ATCC 31461. J. Life Sci. 13, 705-711.

17. Martin, L. O., A. M. Fialho, P. L. Rodrigues, and I. Sa-Correia. 1996. Gellan gum production and activity of biosynthetic enzymes in Sphingomonas paucimobilis mucoid and non-mucoid variants. Biotechnol. Appl. Biochem. 4, 47-54.

18. Morrison, N. A., G. Sworn, R. C. Clark, Y. L. Chen, and T. Talashek. 1999. Gelatin alternatives for the food industry. Prog. Coll. Polym. Sci. 114, 127-131.

19. Sá-Correia, I., A. M. Fialho, P. Videria, L. M. Moreira, A. R. Marques, and H. Albano. 2002. Gellan gum biosynthesis in Sphingomonas paucimobilis ATCC 31461: genes, enzymes and exopolysaccharide production engineering. J. Ind. Microbiol. Biotechnol. 29, 170-176.

20. Schilling, B. M., U. Rau, U. T. Maier, and P. Fankhause. 1999. Modeling and scale-up of the unsterile scleroglucan production process with Sclerotium rolfsii ATCC 15205. Bioprocess Eng. 20, 195-201.

21. Wang, X., Y. Yuan, C. Liu, D. Zhang, Z. Yang, C. Yang, and C. Ma. 2006. Modeling for gellan gum production by Sphingomonas paucimobilis ATCC 31461 in a simplified medium. Appl. Environ. Microbiol. 72, 3367-3374.

22. West, T. P. 2002. Isolation of a mutant strain Pseudomonas sp. ATCC 31461 exhibiting elevated polysaccharide production. J. Ind Microbiol. Biotechnol. 29, 185-188.

23. Yan, G.., G. Du, Y. Li, J. Chen, and J. Zhong. 2005. Enhancement of microbial transaminase production by Streptoverticillium mobaraens: application of a two-stage agitation speed control strategy. Process Biocehm. 40, 963-968.

24. Zheng, M. Y., G. C. Du, J. Chen, and W. F. Guo. 2001. A temperature-shift strategy in batch MTG fermentation with S. mobaraense. Process Biochem. 36, 525-530.

25. Zheng, M. Y., G.. C. Du, and J. Chen. 2002. pH control strategy of batch microbial transglutaminase production with Streptoverticillium mobaraense. Enzyme Microb. Technol. 31, 477-481. 


\section{초록 : Sphingomonas paucibilis NK-2000 균주가 생산하는 젤란의 생산 농도 향상을 위한 포도당 첨가 및 교반속도와 통기량 변화 방법의 최적화}

이남규 $\cdot$ 서형필 · 조영배 $\cdot$ 손창우 ${ }^{1} \cdot$ 고 와 ${ }^{2,3} \cdot$ 이진우 $2,4 *$

(해양생물산업육성센터, ${ }^{1}$ 한국바이오솔루션, ${ }^{2}$ 동아대학교 BK21 생물자원 실버바이오사업 인력양성사업단, ${ }^{3}$ 동아대학교 대학원 의생명과학과, ${ }^{4}$ 동아대학교 생명공학과)

Sphingomnas paucibilis NK2000 균주를 사용한 젤란의 최적 교반속도 및 통기량은 각각 $400 \mathrm{rpm}$ 및 $1.0 \mathrm{vvm}$ 이 었다. 이 균주를 사용하여 젤란의 생산성을 향상시키기 위한 포도당의 최적 첨가시기는 배양을 시작한 36시간 이었다. 젤란의 생산성을 향상시키기 위한 5가지 방법, 1) 포도당을 첨가하지 않는 방법, 2) 배양 36시간 후에 포 도당을 첨가하지만 교반속도 및 통기량을 변화시키지 않는 방법, 3) 배양 36 시간 후에 포도당을 첨가하고 교반속 도를 $400 \mathrm{rpm}$ 에서 $600 \mathrm{rpm}$ 으로 변화시키는 방법, 4) 배양 36 시간 후에 포도당을 첨가하고 교반속도를 $400 \mathrm{rpm}$ 에서 $600 \mathrm{rpm}$ 으로 증가시키고 통기량을 $1.0 \mathrm{vvm}$ 에서 $1.5 \mathrm{vvm}$ 으로 증가시키는 방법 및 5) 배양 36 시간 후에 포도당을 첨가하고 교반속도를 $400 \mathrm{rpm}$ 에서 $600 \mathrm{rpm}$ 으로 증가시키고 통기량을 $1.0 \mathrm{vvm}$ 에서 $2.0 \mathrm{vvm}$ 으로 증가 시키는 방법 등을 실험한 결과, 젤란의 생산성은 각각 $5.19,5.74,6.73,7.93$, 및 $9.40 \mathrm{~g} / 1$ 이었으며, 변환률은 각각 $26.0,19.1,22.4,26.4$, and $31.3 \%$ 이었다. 최적의 방법으로 생산한 젤란의 생산농도 및 포도당 전환율은 포도당을 첨가하지 않은 방법으로 생산한 젤란의 생산농도 및 포도당 전환율에 비하여 각각 1.81 및 1.20 배 증가하였다. 